\title{
Real-world data suggest that geriatric assessment fails to stratify risk in treating older adults with lung cancer
}

Dados do mundo real sugerem que a avaliação geriátrica falha em estratificar o risco no tratamento de adultos mais velhos com câncer de pulmão

Mauro Daniel Spina Donadio ${ }^{1}$, Audrey Cabral F Oliveira ${ }^{1}$, Luciana Leite Moura', Victor Hugo Fonseca de Jesus ${ }^{1}$, Tiago Cordeiro Felisimino' ${ }^{1}$, Aldo Lourenço Abbade Dettino ${ }^{1}$

\begin{abstract}
Introduction: Older adults require attention to risks of treatment toxicity. The purpose of this study was to evaluate epidemiological data and clinical outcomes of patients with lung cancer treated with non-curative intent assessed by geriatric assessment (GA) and restricted access to new therapies. Methods: We evaluated older adults with non-small cell lung cancer treated with palliative chemotherapy or first generation target therapy who underwent GA. Overall survival (OS) was calculated and we performed univariate and multivariate analysis to determine prognostic factors for OS. Results: Fifty-four patients aged $\geq 70$ years had a median age of 76 years, $76 \%$ was classified as Katz A and $50 \%$ as Lawton $<27.68 .5 \%$ were at risk of malnutrition or malnourished; $61.1 \%$ had $\geq 2$ comorbidities. The mean OS was 17.1 months. In the univariate analysis, lower survival results were observed for patients with $E C O G \geq 2(H R=5.9 ; p<0.001)$, higher number of metastasis sites $(H R=2.0 ; p=0.04)$ and liver metastasis $(H R=12.6 ; p<0.001)$. In multivariate analysis, male gender, $E C O G \geq 2$, more than 2 metastatic sites and liver metastases were associated with higher risk of death. We did not observe differences in survival according to functional capacity. Conclusion: GA showed no prognostic relationship in our small population. Patients with ECOG $\geq 2$, more than 2 metastatic sites and hepatic metastasis presented higher risk of death. For the older population, new treatment modalities are fundamental and outweigh the prognostic importance of the clinical factors of GA.
\end{abstract}

Keywords: Geriatric assessment; Lung neoplasms; Frail elderly.

\footnotetext{
1. AC Camargo Cancer Center, Clinical Oncology - São Paulo - São Paulo - Brazil Financial support: none to declare.

Conflicts of interest: The authors declare no conflict of interest relevant to this manuscript.

Correspondence author: Mauro Daniel Spina Donadio .

E-mail: maurodsd@gmail.com / mauro.donadio@accamargo.org.br
} 


\begin{abstract}
RESUMO
Introdução: Os adultos mais velhos requerem atenção quanto aos riscos de toxicidade do tratamento. O objetivo deste estudo foi avaliar dados epidemiológicos e desfechos clínicos de pacientes com câncer de pulmão tratados com intenção não curativa submetidos a avaliação geriátrica (AG) e acesso restrito a novas terapias. Métodos: Avaliamos idosos com câncer de pulmão de células não pequenas tratados com quimioterapia paliativa ou terapia-alvo de primeira geração que realizaram AG. A sobrevida global (SG) foi calculada e realizamos análises univariadas e multivariadas para determinar os fatores prognósticos para SG. Resultados: Cinquenta e quatro pacientes com idade $\geq 70$ anos tinham uma idade mediana de 76 anos, 76\% foram classificados como: Katz A e 50\% como Lawton $<27.68,5 \%$ estavam em risco de desnutrição ou desnutrição; $61,1 \%$ tinham $\geq 2$ comorbidades. O SG médio foi de 17,1 meses. $\mathrm{Na}$ análise univariada, piores resultados de sobrevida foram observados para pacientes com $E C O G \geq 2(H R=5,9 ; p<0,001)$, maior número de locais de metástase $(H R=2,0 ; p=0,04)$ e metástases hepáticas ( $H R=12,6 ; p<0,001)$. Na análise multivariada, sexo masculino, ECOG $\geq 2$, mais de 2 locais metastáticos e metástases hepáticas foram associados a maior risco de morte. Não observamos diferenças na sobrevida de acordo com a capacidade funcional. Conclusão: AG não mostrou relação prognóstica em nossa pequena população. Pacientes com ECOG 2 , mais de 2 locais metastáticos e metástases hepáticas apresentaram maior risco de morte. Para a população idosa, novas modalidades de tratamento são fundamentais e superam a importância prognóstica dos fatores clínicos da AG.
\end{abstract}

Descritores: Avaliação geriátrica; Neoplasias pulmonares; Idoso frágil.

\section{INTRODUCTION}

In the coming decades the elderly population will make up about $20 \%$ of the total population and the percentage of patients over 75 and over 85 will increase disproportionately. The importance of this demographic trend is magnified by the sharp increase in the incidence of most cancers after age 60 . Currently, approximately 50 percent of all malignancies and 70 percent of cancer deaths occur in those $\geq 65$ years of age and this fraction tends to increase. ${ }^{(1-3)}$

Older adult (OA) patients require special attention to the risks of chemotherapy (treatment-related toxicities and quality of life issues). Aging is associated with decreased organ functions, muscle wasting, multiple comorbidities, polypharmacy with likelihood of harmful drug interactions and risk of adherence to therapy. ${ }^{(4-16)}$ For critically ill patients with severe comorbid disease that results in an estimated short life span (particularly one year or less) the risks of chemotherapy often outweigh their benefits. Older patients, then, are at risk for decompensation due to exposure to severe metabolic stresses such as chemotherapy and most of these patients should receive supportive care rather than chemotherapy, with attention to symptom palliation. ${ }^{(17)}$

Thus, age and comorbidities may limit the ability of full cancer treatment for advanced non-small cell lung cancer (NSCLC). The median age of newly diagnosed NSCLC patients in developed countries is approximately 68 years and up to $40 \%$ are aged $\geq 70$ years at diagnosis. ${ }^{(18)}$ In addition, patients with limited or low performance status (PS) [ECOG $\geq 2$ or Karnofsky Performance Status (KPS) $\leq 70$ ] comprise 30 to 40 percent of patients with advanced NSCLC. ${ }^{(19)}$ About one third of patients with metastatic disease and most patients who are in the other stages of the disease are not able to undergo a potentially curative surgical resection. ${ }^{(20)}$

The most current first-line palliative treatment options for these patients comprise oral target therapy, immunotherapy and chemotherapy combinations, all with robust survival benefits when compared to chemotherapy alone.(21-27) Target therapies, tyrosine kinase inhibitor (TKI) against EGFR, ALK, ROS1, and NTRK, require specific molecular tests to detect the mutations and predict response to these drugs.(21-24) The indication of isolated or combined checkpoint inhibitors also requires specific tests to evaluate expression of PD-L1.(25,26) And, once target TKI mutations or high PD-L1 expression are excluded, combinations of chemotherapy with immunotherapy have become the standard treatment.(27) However, these treatments require specific tests that are not accessible and, in fact, new less toxic therapies are very restricted for the vast majority of patients in emerging countries, imposing the use of traditional chemotherapies or first-generation target therapies as the only treatment option despite all the recent advances in lung cancer therapies.

Regarding chemotherapy treatment for lung cancer in older patients, some studies show that appropriately selected patients and those with borderline performance status (PS 2), chemotherapy can 
improve overall survival without adversely affecting quality of life compared to the best supportive care for advanced NSCLC. ${ }^{(28-30)}$ The American Society of Clinical Oncology Guideline for Geriatric Oncology and a panel of European experts have not definitively resolved the issue of combination versus mono chemotherapy for patients with advanced NSCLC who are older or have low PS. ${ }^{(31,32)}$

The aim of this study was to evaluate the clinical data and outcomes of an elderly population with lung adenocarcinoma undergoing palliative treatment with chemotherapy or first-generation target therapy after comprehensive geriatric assessment (GA) to attempt to determine detectable prognostic factors in a scenario of scarce resources, as is the case of most oncology services in emerging countries, which do not always have access to molecular testing, lastgeneration TKI and/or immunotherapy.

\section{METHODS}

A retrospective analysis was performed by collecting clinical data from the electronic medical records of patients with stage IIIB and IV lung adenocarcinoma aged 70 years or older diagnosed and treated with chemotherapy or first- generation TKI in $1^{\text {st }}$ or $2^{\text {nd }}$ line between January 2007 to December 2015 in the AC Camargo Cancer Center undergoing GA. The definition of GA for the study was evaluation of functional capacity, comorbidities, polypharmacy, and nutritional status. As a basis for analysis, an evaluation table was used containing epidemiological data (age, gender, ethnicity, and care network), specific pathological data (staging, whether initial or relapsing, and number of metastasis sites), known predictive and prognostic data (hemoglobin, ECOG, and presence of driver mutation), comorbidities (smoking, cardiovascular disease, diabetes mellitus, chronic kidney disease, neurological diseases, respiratory disease, smoking, incontinence and fall, polypharmacy ( $\geq 5$ medications), Charlson score index, and Katz and Lawton functional assessments and nutritional status), cancer treatment (chemotherapies or TKI used in $1^{\text {st }}$ and $2^{\text {nd }}$ palliative lines, response rates, and toxicities), and progression or death. Data were tabulated and statistically analyzed to describe the population with frequencies, means and medians. Overall survival (OS) was calculated according to the Kaplan-Meier method, and we performed univariate and multivariate analysis using the Cox method to describe potential prognostic factors for OS, with forced entry of functional capacity.

\section{RESULTS}

Between the periods from January 2007 to December 2015 in AC Camargo Cancer Center, 54 patients aged $\geq 70$ years with pulmonary adenocarcinoma who underwent GA were treated palliatively. Demographical data are presented in Table 1.

The median age was 76 years, ranging from 71 to 88 years. The distribution by gender was equal. Regarding performance status, $22 \%$ had ECOG $\geq 2$ and all were functionally classified according to activities of daily living (ADL) with $76 \%$ of patients classified as Katz $\mathrm{A}$ and $50 \%$ as Lawton $<27$. In the assessment of nutritional status, $68.5 \%$ were at risk of malnutrition or malnourishment (weight loss $>5 \%$ during prior 6 months or $>2 \%$ for patients with low BMI or sarcopenia). The average age-adjusted Charlson comorbidity index was 10 , with $33 \%$ of the population studied above this average; $61 \%$ had at least 2 comorbidities and $48 \%$ had polypharmacy ( $\geq 5$ drugs). Regarding cancer disease, 26 patients had at least 2 metastatic sites. The central nervous system (CNS) was affected in $7.5 \%$ of cases and the liver in $9.3 \%$. At treatment evaluation, $79.6 \%$ of patients

Table 1. Demographic and clinical features of the study population

\begin{tabular}{|c|c|c|c|}
\hline Age (interval) & median: 76 (71-88) & $\begin{array}{l}\text { Nutritional status } \\
\text { Eutrophic } \\
\text { At risk / malnourished }\end{array}$ & $\begin{array}{l}17(31.5 \%) \\
37(68.5 \%)\end{array}$ \\
\hline $\begin{array}{l}\text { Sex } \\
\text { Male } \\
\text { Female }\end{array}$ & $\begin{array}{l}27(50 \%) \\
27(50 \%)\end{array}$ & $\begin{array}{l}\text { Charlson comorbidity index } \\
\qquad \begin{array}{l}\leq 10 \\
>10\end{array}\end{array}$ & $\begin{array}{l}\text { median: } 10 \\
36(67 \%) \\
18(33 \%)\end{array}$ \\
\hline $\begin{array}{l}\text { ECOG } \\
0-1 \\
\geq 2\end{array}$ & $\begin{array}{l}42(78 \%) \\
12(22 \%)\end{array}$ & $\begin{array}{l}\text { Number of comorbidities } \\
\qquad 2 \\
>2\end{array}$ & $\begin{array}{l}\text { median: } 2 \\
33(61 \%) \\
21(39 \%)\end{array}$ \\
\hline $\begin{array}{l}\text { Polypharmacy } \\
\text { No } \\
\text { Yes }\end{array}$ & $\begin{array}{l}28(52 \%) \\
26(48 \%)\end{array}$ & $\begin{array}{l}\text { Liver metastasis } \\
\text { No } \\
\text { Yes }\end{array}$ & $\begin{array}{c}49(90.7 \%) \\
5(9.3 \%)\end{array}$ \\
\hline $\begin{array}{l}\text { Katz } \\
\text { A } \\
\text { Non-A }\end{array}$ & $\begin{array}{l}41(76 \%) \\
13(24 \%)\end{array}$ & $\begin{array}{c}\text { Number of metastatic sites } \\
\qquad 2 \\
\geq 2\end{array}$ & $\begin{array}{l}\text { median: } 1 \\
28(52 \%) \\
26(48 \%)\end{array}$ \\
\hline $\begin{array}{l}\text { Lawton } \\
27 \\
<27\end{array}$ & $\begin{array}{l}27(50 \%) \\
27(50 \%)\end{array}$ & $\begin{array}{l}\text { Treatment type } \\
\text { Chemotherapy } \\
\text { Target therapy }\end{array}$ & $\begin{array}{l}43(79.6 \%) \\
11(20.4 \%)\end{array}$ \\
\hline
\end{tabular}

ECOG - Eastern Cooperative Oncology Group. 
underwent chemotherapy and the others received TKI. After a 29-month follow-up, the mean OS was 17.1 months (13.5-27.8 months). In the univariate analysis (Table 2), we observed significantly lower survival results for patients with $E C O G \geq 2$ (Hazard Ratio $[H R]=5.9 ; p<0.001)$, number of metastatic sites $\geq 2$ ( $\mathrm{HR}=2.0 ; p=0.04)$ and presence of liver metastasis $(\mathrm{HR}=12.6 ; p<0.001)$. In multivariate analysis (Table 2), male, ECOG $\geq 2$, more than 2 metastatic sites and the presence of liver metastases were associated with higher risk of death. We did not observe any difference between patients classified according to worse functional capacity (Katz non-A) in univariate or multivariate analysis ( $\mathrm{HR}=1,6 ; p=0,18$ and $\mathrm{HR}=0,64$; $p=0,25$, respectively).

\section{DISCUSSION}

Concerned about optimized NSCLC care in OA who does not have access to new diagnostic tests involving PD-L1 expression, target mutations for TKI and new less toxic treatments, such as immunotherapy and last-generation TKI, we made an assessment of survival outcomes, to correlate them with prognostic factors to define how to continue cancer treatment while offering the only accessible therapy, although outdated, respecting physiological and morbid limitations of this more frail population, seeking to improve the general situation with interventions and minimize toxicities and inadequacies of treatment according to GA.
We note that most patients are at risk of malnutrition or are malnourished and half of them have polypharmacy and do not have maximum independence for instrumental activities of daily living (Lawton <27). In spite of that, comorbidities are not very prevalent (only $40 \%$ had at least 2 comorbidities) and only a third of our patients received a Charlson score above 10. The end result is that almost $80 \%$ of our population has an ECOG 0 or 1. Even though this is not such a frail population, they was at a time immediately preceding access to immunotherapy and the most modern tyrosine kinase inhibitors. Unfortunately, this is still the very reality in most cancer treatment sites in emerging countries. As a result, about $80 \%$ of these patients underwent palliative treatment with single-drug or combination chemotherapy. Unlucky, we were unable to obtain quality data regarding the toxicity of treatments that would allow better correlation with survival outcomes.

In our study, we found that the main prognostic factors that negatively impacted the OS on univariate analysis were ECOG $\geq 2$, more than 2 sites of metastasis and presence of liver metastasis, which was present in a minority of the patients. This could explain the beyond expected median survival of 17.1 months after a median follow-up of 29 months. In multivariate analysis, these factors plus male gender were associated with higher risk of death. Malnutrition, although very prevalent in our sample,

Table 2. Prognostic factors for overall survival.

\begin{tabular}{|c|c|c|c|c|c|c|}
\hline & Univariate & analysis & & & Multivariate & analysis \\
\hline Variable & $\mathrm{HR}$ & $95 \% \mathrm{Cl}$ & $P$ value & $\mathrm{HR}$ & $95 \% \mathrm{Cl}$ & P value \\
\hline \multicolumn{7}{|l|}{ Sex } \\
\hline Male & 1.7 & $0.86-3.5$ & 0.11 & 4.14 & $1.5-11.8$ & 0.94 \\
\hline Female & 1 & - & & 1 & - & \\
\hline \multicolumn{7}{|l|}{ ECOG } \\
\hline $0-1$ & 1 & - & & 1 & - & \\
\hline$\geq 2$ & 5.9 & $2.6-13.0$ & $<0.001$ & 10.6 & $1.9-59.5$ & 0.18 \\
\hline \multicolumn{7}{|l|}{ Nutritional status } \\
\hline Eutrophic & 1 & - & & 1 & - & \\
\hline At risk / malnourished & 2.1 & $0.9-4.4$ & 0.047 & 1 & $0.4-2.7$ & 0.33 \\
\hline \multicolumn{7}{|l|}{ Katz } \\
\hline$A$ & 1 & - & & 1 & - & \\
\hline Non-A & 1.6 & $0.77-3.6$ & 0.18 & 0.64 & $0.1-2.9$ & 0.25 \\
\hline \multicolumn{7}{|l|}{ Liver metastasis } \\
\hline No & 1 & - & & 1 & - & \\
\hline Yes & 12.6 & $3.6-48.8$ & $<0.001$ & 6.03 & $0.97-37.2$ & 0.4 \\
\hline \multicolumn{7}{|l|}{ Number of metastatic } \\
\hline \multicolumn{7}{|l|}{ sites } \\
\hline$<2$ & 1 & - & & 1 & - & \\
\hline$\geq 2$ & 2 & $1.01-3.9$ & 0.04 & 2.2 & $0.9-5.4$ & 0.59 \\
\hline
\end{tabular}


did not impact survival. After all, the tumor biology and the effectiveness of chemotherapy may have a higher prognostic impact when compared to clinical features that compose GA.

We understand the limitations of this work such as the lack of formalization in the quality of life assessment, the use of the less broad concept of GA, which could also include psychological evaluation, geriatric, neuro-cognitive and socio-financial syndromes, so called comprehensive geriatric assessment (CGA). Still, we found no prognostic impact of functional capacity and this is in agreement with a multicenter, open-label, phase III ESOGIA study that evaluated over four hundred patients $\geq 70$ years with a PS of 0 to 2 and stage IV NSCLC and randomly assigned them between chemotherapy allocation based on performance status (standard arm) and age or CGA (carboplatin-based double for fit patients, docetaxel for vulnerable patients, and best supportive care for frail patients). This trial failed to show differences in treatment failure-free survival (primary endpoint) and OS, but patients experienced significantly less toxicity across all grades ( $85.6 \%$ vs. $93.4 \% ; p=0.015)$ and fewer failures in treatment as a result of toxicity (4.8\% vs. $11.8 \% ; p=0.007)$ compared with patients in the standard arm. ${ }^{(33)}$

This results do not minimize the importance of GA and ideal patient care demand participation of a multidisciplinary team attentive to the care of older cancer patients carrying out a broader geriatric assessment, evaluating and taking care of patients' comorbidities and nutrition, always taking into account the risks of polypharmacy, with dynamically personalizing and individualizing treatment that can provide a better quality of life. ${ }^{(34)}$

Finally, since GA and CGA proved to be an insufficient tool for selecting systemic treatment with more obsolete therapies against NSCLC, promoting broad access to new prognostic and predictive tests and modern therapies could allow not only less toxicity to this fragile population, but mainly gains in overall survival and quality of life. Thus, we should observe a greater governmental effort in favor of this cause, with investments in medical science, reducing the costs of new drugs, promoting greater access to new diagnostic tests and investing in infrastructure of oncology centers and in the training of its specialists. These measures would certainly advance the care of older patients with metastatic lung cancer in emerging countries.

\section{REFERENCES}

1. Lichtman SM. Therapy insight: therapeutic challenges in the treatment of elderly cancer patients. Nat Clin Pract Oncol. 2006 Feb;3:86-93. DOI: https://doi.org/10.1038/ncponc0420

2. Castellón TD, Sieving KE. An experimental test of matrix permeability and corridor use by an endemic understory bird. Conserv Biol. 2006;20(1):135-45. DOI: https://doi.org/10.1111/ j.1523-1739.2006.00332.x
3. Yancik R, Ries LA. Cancer in older persons: an international issue in an aging world. Semin Oncol. 2004 Apr;31(2):128-36. DOI: https://doi. org/10.1053/j.seminoncol.2003.12.024

4. Sawhney R, Sehl M, Naeim A. Physiologic aspects of aging: impact on cancer management and decision making, part I. Cancer J. 2005 Nov;11(6):449-60. DOI: https://doi. org/10.1097/00130404-200511000-00004

5. Sehl M, Sawhney R, Naeim A. Physiologic aspects of aging: impact on cancer management and decision making, part II. Cancer J. 2005 Nov;11(6):461-73. DOI: https://doi. org/10.1097/00130404-200511000-00005

6. Baumgartner RN, Koehler KM, Gallagher D, Romero L, Heymsfield SB, Ross RR, et al. Epidemiology of sarcopenia among the elderly in New Mexico. Am J Epidemiol. 1998 Apr;147(8):755-63. DOI: https://doi.org/10.1093/ oxfordjournals.aje.a009520

7. Kim TN, Yang SJ, Yoo HJ, Lim KI, Kang HJ, Song W, et al. Prevalence of sarcopenia and sarcopenic obesity in Korean adults: the Korean sarcopenic obesity study. Int J Obes (Lond). 2009 Jun;33:88592. DOI: https://doi.org/10.1038/ijo.2009.130

8. Rolland $Y$, Lauwers-Cances $V$, Cristini C, Van Kan GA, Janssen I, Morley JE, et al. Difficulties with physical function associated with obesity, sarcopenia, and sarcopenic-obesity in community-dwelling elderly women: the EPIDOS (EPIDemiologie de l'OSteoporose) Study. Am J Clin Nutr. 2009 Jun;89(6):1895-900. DOI: https:// doi.org/10.3945/ajen.2008.26950

9. YancikR, Ries LA. Cancer in older persons. Magnitude of the problem--how do we apply what we know? Cancer.1994;74(Suppl7):1995-2003.DOI:https://doi. org/10.1002/1097-0142(19941001)74:7+<1995::aidcncr2820741702>3.0.c0;2-y

10. Vestal RE. Aging and pharmacology. Cancer. 1997;80(7):1302-10.DOI:https://doi.org/10.1002/ (sici)1097-0142(19971001)80:7<1302::aidcncr16>3.0.co;2-b

11. Kivistö KT, Kroemer HK, Eichelbaum M. The role of human cytochrome P450 enzymes in the metabolism of anticancer agents: implications for drug interactions. $\mathrm{Br} \mathrm{J}$ Clin Pharmacol. 1995 Dec;40(6):523-30. DOI: https://doi. org/10.1111/j.1365-2125.1995.tb05796.x

12. Tam-McDevitt J. Polypharmacy, aging, and cancer. Oncology (Williston Park). 2008 Aug;22(9):1052-5.

13. Partridge $A H$, Wang $P S$, Winer EP, Avorn J. Nonadherence to adjuvant tamoxifen therapy in women with primary breast cancer. J Clin Oncol. 2003;21(4):602. DOI: https://doi.org/10.1200/ JCO.2003.07.071

14. Partridge AH, Avorn J, Wang PS, Winer EP. Adherence to therapy with oral antineoplastic agents. J Natl Cancer Inst. 2002 May;94(9):65261. DOI: https://doi.org/10.1093/jnci/94.9.652 
15. Partridge $A H$, LaFountain A, Mayer E, Taylor BS, Winer E, Asnis-Alibozek A, et al. Adherence to initial adjuvant anastrozole therapy among women with early-stage breast cancer. J Clin Oncol. 2008;26(4):556. DOI: https://doi. org/10.1200/JCO.2007.11.5451

16. Partridge $\mathrm{AH}$. Non-adherence to endocrine therapy for breast cancer. Ann Oncol. 2006 Feb;17(2):183-4. DOI: https://doi.org/10.1093/ annonc/mdj141

17. Yancik R, Wesley MN, Ries LA, Havlik RJ, Long S, Edwards BK, et al. Comorbidity and age as predictors of risk for early mortality of male and female colon carcinoma patients: a populationbased study. Cancer. 1998 Jun;82(11):2123-34.

18. Howlader NNA, Krapcho M, et al. SEER Cancer Statistics Review. 1975-2010 [Internet]. Bethesda: National Cancer Institute (NIH); 2013. Available from: http://seer.cancer.gov/csr/1975_2010/

19. Lilenbaum RC, Cashy J, Hensing TA, Young S, Cella D. Prevalence of poor performance status in lung cancer patients: implications for research. J Thorac Oncol. 2008 Feb;3(2):125-9. DOI: https:// doi.org/10.1097/JTO.0b013e3181622c17

20. Hardy D, Liu CC, Cormier JN, Xia R, Du XL. Cardiac toxicity in association with chemotherapy and radiation therapy in a large cohort of older patients with non-small-cell lung cancer. Ann Oncol. 2010 Sep;21(9):1825-33. DOI: https://doi. org/10.1093/annonc/mdq042

21. Shah R, Lester JF. Tyrosine kinase inhibitors for the treatment of EGFR mutation-positive nonsmall-cell lung cancer: a clash of the generations. Clin Lung Cancer. 2020 May;21(3):e216-e28. DOI: https://doi.org/10.1016/j.cllc.2019.12.003

22. McCusker MG, Russo A, Scilla KA, Mehra KA, Rolfo C. How I treat ALK-positive non-small cell lung cancer. ESMO Open. 2019 Jan;4(Suppl 2):e000524. DOI: https://doi.org/10.1136/ esmoopen-2019-000524

23. Lin JJ, Shaw AT. Recent advances in targeting ROS1 in lung cancer. J Thorac Oncol. 2017 Nov;12(11):1611-25. DOI: https://doi. org/10.1016/j.jtho.2017.08.002

24. Ricciuti B, Brambilla M, Metro G, Baglivo S, Matocci R, Pirro $M$, et al. Targeting NTRK fusion in non-small cell lung cancer: rationale and clinical evidence. Med Oncol. 2017 Jun;34(6):105. DOI: https://doi.org/10.1007/s12032-017-0967-5

25. Chen $R$, Tao $Y, X u X$, Shan $L$, Jiang $H$, Yin $Q$, et al. The efficacy and safety of nivolumab, pembrolizumab, and atezolizumab in treatment of advanced non-small cell lung cancer. Discov Med. 2018 Oct;26(143):155-66.
26. Hellmann MD, Paz-Ares L, Caro RB, Zurawski B, Kim SW, Costa EC, et al. Nivolumab plus ipilimumab in advanced non-small-cell lung cancer. N Engl J Med. 2019 Nov;381(21):2020-31. DOI: https://doi.org/10.1056/NEJMoa1910231

27. Judd J, Borghaei H. Combining immunotherapy and chemotherapy for non-small cell lung cancer. Thorac Surg Clin. 2020 May;30(2):199-206. DOI: https://doi.org/10.1016/j.thorsurg.2020.01.006

28. Zukin $M$, Barrios $\mathrm{CH}$, Pereira JR, Ribeiro RA, Beato CA, Nascimento YN, et al. Randomized phase III trial of single-agent pemetrexed versus carboplatin and pemetrexed in patients with advanced non-small-cell lung cancer and Eastern Cooperative Oncology Group performance status of 2. J Clin Oncol. 2013;31(23):2849-53. DOI: https://doi.org/10.1200/JCO.2012.48.1911

29. The Elderly Lung Cancer Vinorelbine Italian Study Group. Effects of vinorelbine on quality of life and survival of elderly patients with advanced non-smallcell lung cancer.J Natl Cancer Inst. 1999 Jan;91(1):6672. DOI: https://doi.org/10.1093/jnci/91.1.66

30. Kudoh S, Takeda K, Nakagawa K, Takada M, Katakami N, Shinkai KM, et al. Phase III study of docetaxel compared with vinorelbine in elderly patients with advanced non-small-cell lung cancer: results of the West Japan Thoracic Oncology Group Trial (WJTOG 9904). J Clin Oncol. 2006;24(22):3657. DOI: https://doi.org/10.1200/JCO.2006.06.1044

31. Azzoli CG, Baker Junior S, Temin S, Pao W, Aliff $\mathrm{T}$, Brahmer J, et al. American Society of Clinical Oncology Clinical Practice Guideline update on chemotherapy for stage IV non-small-cell lung cancer. J Clin Oncol. 2009;27:6251. DOI: https:// doi.org/10.3779/j.issn.1009-3419.2010.03.15

32. Gridelli C, Ardizzoni A, Le Chevalier T, Manegold C, Perrone F, Thacher N, et al. Treatment of advanced non-small-cell lung cancer patients with ECOG performance status 2: results of an European Experts Panel. Ann Oncol. 2004;15(3):419-26. DOI: https://doi.org/10.1093/annonc/mdh087

33. Corre R, Greillier L, Le Caër H, AudigerValette C, Baize N, Falchero $\mathrm{HB}$, et al. Use of a comprehensive geriatric assessment for the management of elderly patients with advanced non-small-cell lung cancer: the phase III randomized ESOGIA-GFPC-GECP 08-02 study. J Clin Oncol. 2016;34(13):1476-83. DOI: https:// doi.org/10.1200/JCO.2015.63.5839

34. Dettino A, Figueroa MCM, Leite AMM, Chinen LTD, Nicolau UR, Sanches SMS, et al. Geriatric oncology: comprehensive geriatric assessment tools (CGA) implementation and interdisciplinary clinical approach for elderly patients (pts) in AC Camargo Cancer Center (ACCCC), São Paulo, Brazil. J Clin Oncol. 2014;32(Suppl 15):9549. DOl: https://doi. org/10.1200/jco.2014.32.15_suppl.9549 